\title{
Paul Valéry and the Search for Poetic Rhythm
}

\author{
DAVID EVANS
}

\begin{abstract}
:
Throughout his theoretical writings, Valéry insists on two fundamental principles: poetic rhythm is undefinable and yet it is central to poetry. Although his verse practice evolves from irregularity to regularity, Valéry insists that predictable metrical forms are no guarantee of poeticity, and rejects the Romantic model of rhythmic mimesis based on the cosmos, nature or the human body. It is not by confirming the meaningfulness of regular patterns, therefore, that poetic rhythm signifies; rather, the complex overlapping of multiple, elusive and unanalysable rhythms provides a source of questions to which the answer is constantly deferred; and that, for Valéry, is the definition of poetry.
\end{abstract}

Keywords: Valéry, Cahiers, rhythm, rhyme, versification, metre, beauty, constellations, deferral

The work of Paul Valéry (1871-1945) emerges from and contributes to a radical reconceptualisation of poetic rhythm, beginning with his acquaintance with Mallarmé, and a passion for his poetry, in the 1890s. Although Valéry's poetic production was quite limited, his theoretical writings filled countless notebooks (cahiers) with detailed reflections on the processes of composition and reading; while his verse amounts to the short monologue La Jeune Parque (The Young Fate), a brief Album de vers anciens (Album of Old Verses) and the twenty-one poems of Charmes (Charms), he wrote the Cahiers without interruption from the late 1890 s to his death. Valéry offers some of the most rigorous, lucid, complex and above all, healthily sceptical thinking on the meaning of post-crisis rhythm. His analysis is not limited to literature - he explores rhythm as a characteristic of memory, motor functions, perception, the natural world, as well as in the composition and reception of the arts - but given the vast scope, and sheer amount, of Valery's writings on the subject, I will restrict myself here to his analyses of rhythm as a central feature of poetry. Valéry's thinking is invaluable because, first and foremost, he insists throughout his life on

Paragraph 33:2 (2010) 158-175

DOI: $10.3366 / \mathrm{E} 0264833410000829$ 
the impossibility of defining rhythm satisfactorily:

Rhythm. Very hard to analyse, this notion. (Cahiers, 1914-15, V, 499) ${ }^{1}$

This word 'rhythm' is not clear to me. (Cahiers, 1915, V, 541)

I have read or composed twenty 'definitions' of Rhythm, none of which I adopt. (E, I, 1289)

Rhythm - no objective definition. To define it would be to produce it. (Cahiers, 1938, XXI, 14)

While acknowledging rhythm's undefinability, though, Valéry never ceases investigating it as a scholar and poet, constantly questioning the value of metrical verse. The eighteen-year old Valéry writes to Charles Boès in 1889, 'I believe in the all-powerfulness of rhythm' (CE, I, 1574) and line five of 'Orphée' (1891 version) reads: 'Le dieu chante, et selon le rythme tout puissant' (the god sings, and by the all-powerful rhythm); and while this youthful enthusiasm for rhythm never abates, the relationship between rhythm, poetry and verse is never taken for granted.

The Album de vers anciens (1920) contains poems mostly written between 1890 and 1893 in traditional metrical form: mainly alexandrines, the centuries-old twelve-syllable line with an obligatory pause, or caesura, halfway through coinciding with a break in the sense: 'Le chant clair des rameurs / enchaine le tumulte' (The clear song of the rowers enslaves the tumult) ('Hélène', 1. 11). Yet within that regular form, in keeping with a precedent set, notably, by Baudelaire, Rimbaud, Verlaine, Banville, Laforgue and Mallarmé, Valéry includes an extremely high proportion of ametrical lines, where the caesura falls mid-word or after an unaccentuable schwa. ${ }^{2}$ Moreover, many of these metrically irregular lines deal with music and nature, suggesting that poetic rhythm does not lie in an outdated Romantic analogy between a musical universe and metrical verse:

Où le jardin mélo / dieux se dodeline ('La Fileuse', 1.3)

(Where the melodious garden nods its head)

Les hauts murs d'or harmo / nieux d'un sanctuaire ('Orphée', 1.9)

(The high walls, of harmonious gold, of a sanctuary)

Une goutte tombe / de la flûte sur l'eau ('Épisode', 1.18)

(A drop falls from the flute onto the water)

Entendre l'onde se / rompre aux degrés sonores ('Hélène', 1.2)

(Hearing the wave break in sonorous degrees) 
In this last example, the rhythms of metrical verse and the waves are in conflict, breaking the anticipated balance of the line rather than mapping onto each other as in Victor Hugo, for example. Similar rhythmic disturbances occur at the line end, with enjambement displacing the accent from the rhyme word to the next line: 'que l'Océan constelle / D'écume' ('which the Ocean constellates / With spray', 'Été', 11.29-30). Whereas the rhythms of the sea are synonymous with verse in Romantic poetry, here the sea-spray, scattered in the air, disturbs rather than confirms metrical structures. Poetic rhythm, for Valéry, may be all-powerful, but already in his early verse, it is clearly not synonymous with predictable, fixed metre and rhyme.

While the early twentieth century saw French free verse blossom, Valéry's verse seemed to return to regularity. La Jeune Parque (1917), on which Valéry worked while editing his early verse, is remarkable for alexandrines where syntax and metre coincide, and from over 500 lines, almost all observe a strong caesura and a firm 6-6 rhythm. As Valéry explained in 1941, 'I insisted (...) on observing the rules of classical prosody, on being even more rigorous, perhaps' (CE, I, 1614). Similarly, Charmes (1922), which Valéry describes as 'a collection of prosodic experiments, ${ }^{3}$ displays a wide variety of canonical stanzaic and metrical forms from pentasyllable to dodecasyllable, all with their roots in the French tradition stretching back to the late medieval period and the Renaissance, and with several influenced by Hugo. As well as their hearty embrace of metrical structures, the last two volumes are noteworthy for the frequency of rimes léonines, extremely rich rhymes whose rhyming phonemes stretch over two or more syllables, strengthening the parallelism between isometric lines, an effect further emphasised by the short metres:

Fin suprême, étincellement (...)

Proclame universellement ('Ode secrète', 11.21-4)

It would be tempting to interpret this enthusiasm for reinforcing metrical structures as a return to a simplistic belief in rhythmic regularity and traditional verse form. Valéry insists, however, that the poetic value of regularity is unstable, arguing in his cahiers that 'The principle is the music of verse. Rhyme richness can contribute to it. It can also detract from it' (Cahiers, 1914, V, 273). Furthermore, in his writings on poetry he constantly classifies rhythm separately from metre and number when discussing formal techniques, such as 'rhythmics, metrics and prosody' ('Questions de poésie', E, I, 1293). 
Indeed, Valéry clearly states that 'Feeling the rhythm or the nonrhythm is entirely independent from the counting (dénombrement)' (Cahiers, 1915, V,543).

Intriguingly, given the evolution of his verse practice towards predictable regularity, Valéry repeatedly equates the mechanisms of metrical verse with the death of poetry. Bad verse, he writes, gives the impression of being an 'automatic mechanism' (Cahiers, 1910, IV: 485), and of Hugo's verse he writes disparagingly, 'nothing is more strictly mechanical' (Cahiers, 1915, V, 667). When Boileau codified verse, this was seized upon by inferior minds, who 'could prove by counting on their fingers that the verse was good' (Cahiers, 1917, VI, 748). Thus, he argues:

The classical rules of French verse - almost impossible to justify as a whole, easy to remember like a decree, difficult to observe without writing nonsense, since most of one's art is spent on satisfying them; their clarity allowing someone, with no ear and with no poetry, to judge poets; conventional rules; societal; very likely to make for ridiculous verse, to submit the man who sings to the man who can count to twelve. (Cahiers, 1916, VI, 202)

Similarly, despite his own extravagantly rich rhymes in Charmes, Valéry disagrees with 'the idea of making rich rhyme a mechanical criterion. An artist whoever respected it. Not an artist whoever sacrificed it' (Cahiers, 1914, V, 273). The mistake of the Parnassian school, for Valéry, lay in their defining too rigidly the formal elements of beauty:

They defined the 'beautiful line of verse' too precisely. As a result, any poet could measure himself accurately by the overall amount of his verse compared to the number of beautiful lines. (...) Whenever beauty becomes determined like that, it becomes facile. (Cahiers, 1915, V, 882)

For Valéry, it is this excessive formal prescriptivism which precipitated the crisis in French verse, whereas what is needed now, on the contrary, is 'la beauté informulée' (unformulated beauty) which depends on 'ce qui reste d'informe' (what remains of the formless). In his important 'Discours sur l'esthétique' (1937), Valéry observes that Beauty will always elude scientific analysis, since no formula can account for, or prescribe, a sufficiently wide variety: "The very idea of a "Science of Beauty" was destined to be undermined by the diversity of beauties produced or recognised in the world over time' (E, I, 1302).

While Valéry does not in practice discard regular metrical conventions, then, these conventions do not provide the rhythmic proof of poetry, nor does their presence in a work guarantee its 


\section{Paragraph}

poeticity. Rather, just as Virginia Woolf, in the epigraph to Emma Sutton's essay in this volume, presents rhythm as a wave, not monotonously regular, but rather, breaking and tumbling in the mind, Valéry argues that poetry be redefined as an 'undulatory mechanism!' (Cahiers, 1927, XII, 275). The notion of a mechanical device remains, but in practice, poetic rhythm requires the performance of a regularity which the skill of the poet must somehow make us forget: "How ridiculous the scansion of metrical verse - Reducing music to beating time, whereas music consists of making you forget the beat while nonetheless sticking to it rigorously' (Cahiers, 1940, XXIII, 197). The active, multiple nature of this new rhythmical model is highlighted by Valéry's explanation of how rhythm functions in a succession of rhymed alexandrine couplets such as those of La Jeune Parque, which adheres to the conventional alternation of masculine (ending in a consonant) and feminine (ending in an 'e') rhymes:

There is a sort of rhythm particular to the alexandrine which lies in the combination of the phrase and the rhyme-you have in the series MMFFMMFFMMFF the combinations MM, or FF, or MF, or FM, ie. a perfect couplet MM, FF, or a mixed couplet FM, MF.

This rhythm is in addition to all the other kinds of rhythms. (Cahiers, 1918, VII, 636)

Conventional verse, then, provides a framework in which multiple rhythms are superimposed and performed simultaneously, set to work with and against each other as an irresolvable process, and it is this complexity which defines the experience of poetic rhythm for Valéry; free verse lacks the basic metrical blueprint against which other patterns can be experienced in counterpoint. ${ }^{4}$

\section{The fallacy of rhythmic mimesis}

One of the most crucial features of Valéry's thinking on rhythm, in terms of his importance to the post-Mallarmean poetic landscape, is his refusal to see any meaning in the natural world beyond that which the human mind attributes to it, thereby severing any Romantic links between verse form and the cosmos. ${ }^{5}$ For Hugo, the stars explicitly proclaim God's presence in the universe:

- Pléiades qui percez nos voiles,

Qu'est-ce que disent vos étoiles?

— Dieu! dit la constellation. ('Les Mages', 11. 18-20) 
('Pleiades, which pierce our veils,

What do your stars express?'

'God!' replies the constellation.)

By contrast, in a famous passage from Valéry's writings on Mallarmé, he recalls walking with the author of the recently completed experimental poem Un Coup de dés ( $A$ Throw of the Dice), and contemplating the stars, which seem to be 'the very text of the silent universe; a text full of clarity and enigmas; as tragic, as indifferent as you like; which speaks and does not speak; a tissue of multiple meanings; which assembles order and disorder; which proclaims a God as powerfully as it denies Him' ('Un Coup de dés', 1920, E, I, 626). The constellations are neither a random, meaningless jumble, nor proof of a divine presence; it is their very inscrutability which is so captivating, tempting us to see meaningful structures where there may be none at all. Yet since the absence of meaning, in the great French tradition of Pascal and Baudelaire, is a terrifying prospect, it is only human to impose order on the cosmos, as Valéry confirms in 'Ode secrète', from Charmes:

\footnotetext{
O quel Taureau, quel Chien, quelle Ourse, Quels objets de victoire énorme, Quand elle entre aux temps sans ressource L'âme impose à l'espace informe! (11.17-20) (Oh what a Bull, what a Dog, what a Bear, What objects of great victory, When it enters times of no resource, The soul imposes on formless space!)
}

Un Coup de dés itself appeared to Valéry 'comme si une constellation eût paru qui eût enfin signifié quelque chose' (E, I, 624) (as if a constellation had appeared which at last meant something), the pair of imperfect subjunctives maintaining the necessary ambiguity whereby meaning, in the world as in the text, is no longer a stable truth, but rather a tantalizing yet never fully realised possibility. If poetic rhythm, therefore, shares anything with the stars, it is that they both give us the suspicion that meaning is in there somewhere; they inspire us to search for it, tempt us to impose patterns and structures on them, and yet never confirm whether those patterns have any intrinsic value. A defining characteristic of post-crisis rhythm is, similarly, its fundamental resistance to the decoding which it actively invites us to attempt. 


\section{Paragraph}

As well as the stars, another timeless image traditionally presented as embodying the rhythms of the natural world is the sea, with its tidal motion, wave patterns, storms and calm passages making it a tempting metaphor for verse. Walter Ince, for example, claims that in the concluding lines of La Jeune Parque, the rhythms do not just "suggest" the disordered power of wave and water, they are it, transposed into a linguistic experience', while Christine Crow hears 'the ebb-andflow rhythm of the sea in the alexandrine'. 7 Yet for Valéry, the sea could represent 'an oscillation limited in itself', 'a regular phase'; 'The drama, strange at first, seems in its repetition like a machine' (Cahiers, 1911, IV, 503). Valéry rejects the idea that marine rhythms contain any meaning beyond themselves, arguing that regular rhythms are not necessarily inherent in the waves, but rather, are imposed on their complex structures by a human sensibility in search of reassuring order: 'It is impossible, in my opinion, to reduce rhythm to objective observation. That is why I dislike the term Rhythm of the waves which eliminates the senses' (Cahiers, 1935, XVIII, 83). Thus, in the final stanza of 'Le Cimetière marin', after twenty-three stanzas of intense intellectual activity, scrutiny of the natural world, and contemplation of mortality, the wind picks up, disturbing the poet's book, and the joyful waves break the calm waters, shattering the poet's reverie; at this very moment, the traditional 4/6 rhythm of the decasyllable, which has been scrupulously respected in the previous 142 lines, is disrupted by a césure lyrique which places an unaccentuable word-final schwa at the accented fourth syllable. Moreover, recalling the recurrent presence of the sea in the aforementioned metrical disturbances of the Album de vers anciens, it is the unaccentuable 'e' of 'vagues' (waves) itself, after an imperative - 'Rompez' (Break) — which explicitly calls for structural dismantling:

\footnotetext{
L'air immense ouvre / et referme mon livre,

La vague en poudre / ose jaillir des rocs!

Envolez-vous, / pages tout éblouies!

Rompez, vagues! / Rompez d'eaux réjouies (11.140-43)

(The immense air opens and shuts my book,

The powdery wave dares to spring from the rocks!

Fly away, dazzled pages!

Break, waves! Break with joyful waters)
}

In striking contrast with the Romantic belief in the quasi-versificatory rhythms of the natural world - for Hugo, "nature is a symphony; there 
is rhythm and measure everywhere; and you could almost believe that God had made the world in verse' ${ }^{8}$ - here Valéry suggests a fundamental incompatibility between the sea's unpredictable structures and the fixed metrical forms of verse, which was already highlighted by Rimbaud in 'Le Bateau ivre' ('The Drunken Boat'), where the unruly waters engulf and erase the poem's metrical structure. When Valéry's Parque contemplates the waves, searching for the truth of her human condition, she finds that "la houle me murmure une ombre de reproche' (the swell murmurs a hint of a reproach at me); ${ }^{9}$ and in ' $\mathrm{Un}$ feu distinct...', from the Album de vers anciens, instead of confirming the meaningfulness of regular rhythm, the sound of the waves inspires only doubt:

Comme à la vide conque un murmure de mer, Le doute (11.12-13)

(As to the empty shell a murmur of the sea

Doubt)

Thirdly, it often proves extremely tempting for poets and critics alike to imagine a rhythmic truth in the human body, in what appear to be the regular rhythms of our breathing, heartbeat and pulse. Yet while Valéry reflects at length on our psychological, physiological and muscular responses to rhythms of various kinds, he offers no simplistic model of corporeal rhythms corresponding to regular verse. On the contrary, like the stars and the sea, the rhythms governing the human organism are a source of unanswerable questions:

The organism has its stopwatches and its metronomes. What are they? What time has it adopted? What pendulum beats?

These questions, if only we could answer them, would provide the thread and the most intimate link between the body and the cosmos from which it is separated. (Cahiers, 1916, VI, 278)

The young Parque, wrestling with the problematic experience of recognising a rhythmic pulse in herself, finds no solace in the regular beat of a $3 / 3 / 3 / 3$ alexandrine:

Mon cœur bat! / mon cœur bat! / Mon sein brûle / et m’entraîne! (27)

(My heart beats! my heart beats! My breast burns and carries me away)

This regular rhythm provides no answers, nor any confirmation of the meaning of life. As the despairing Parque contemplates suicide, it is precisely the rhythmic part of herself which she intends to 
destroy: 'j'allai de mon cœur noyer les battements' (35) (I went to drown the beating of my heart); and as she contemplates death, her heart's faltering rhythm remains as mysterious as ever:

Écoute, avec espoir, frapper au mur pieux

Ce cœur, - qui se ruine à coups mystérieux (31)

(Listen, with hope, as it knocks on the pious wall,

To this heart, which ruins itself with mysterious beats)

Neither the stars, nor the sea, nor the human body, therefore, can provide a stable guarantee of a meaningful rhythm which pre-exists the text, and Valéry warns us to be sceptical of mimetic textual models of external rhythm. However, the creation and appreciation of artistic, literary or poetic structure is a profoundly human activity, and to deny inherently meaningful forms in nature is not to call for formlessness in art. Just as the human mind is predisposed to impose patterns, the interpretation of artistic structures, or the search for an interpretation, is a matter for the reader: 'Composition is the most human thing about the arts. Nature only offers systems at random; and we have to search for a link which establishes some relation between a whole and its parts. This requires man' (Cahiers, 1931, XIV: 808). Poetic rhythm, therefore, emerges as a constant search for an answer which, we must accept, can never be confirmed by any higher authority, and yet the urge to uncover the truth of this rhythm, the hope of an imminent revelation, remains.

\section{Rhythm and composition}

Given Valéry's dismissal of any extra-textual force producing rhythms for the poetic text to imitate, his insistent claims that several of his poems find their origin in some pre-textual rhythm may seem surprising:

It was born, like most of my poems, from the presence in my mind of a certain rhythm. I was astonished to find, one morning, decasyllabic lines in my head. ${ }^{10}$

As for the Cimetière marin, the intention was at first just an empty rhythmic figure, or filled with vain syllables, which came to obsess me for a while. I observed that this figure was decasyllabic. (CE, I, 1503)

Another poem began in me by the simple indication of a rhythm which gave itself a meaning little by little. (CE, I, 1474) 
My poem Le Cimetière marin started in me with a certain rhythm, which is that of the French decasyllable, divided into four and six. I had no idea yet what should fill that form. (...) Another poem, La Pythie, first offered itself by a line of eight syllables whose sonority composed itself all on its own. (C, I, 1338)

As late as 1944, in the preface to his translation of Virgil's Bucolics into unrhymed alexandrines, Valéry maintains that it is the rhythm which comes first, and that a poet's 'internal work consists less of finding words for his ideas than of finding ideas for his words and predominant rhythms' (CE, I, 212); similarly, as Emma Sutton observes in this volume, Virginia Woolf writes of 'putting words on the backs of rhythm'. We might be puzzled, then, by an apparent return to the idea of a rhythmic truth preceding the text. Yet in the above quotations, Valéry carefully situates the rhythm inside his own mind, not outside; furthermore, his is an extremely well-read mind familiar with the history of French verse forms, having spent many years grappling with the problems of composition. In this context, we might not be as surprised as he himself claims to be when he writes of composing almost unconsciously in metrical form: 'I was surprised to find myself versifying' (E, I, 1492). As such, poetic rhythm becomes a selfreflexive activity, reflecting only other textual models rather than a truth 'out there' in the world.

Such is Valéry's insistence on the role of a self-contained and selfperpetuating literary tradition in maintaining formal conventions, that he wonders whether anyone would invent verse had it not been bequeathed to them:

If literature had not existed before now - nor verse - would I have invented them? - Would our era have invented them? (Cahiers, 1917, VI, 566)

No-one would invent verse today, if it was not inherited. - Nor religions, for that matter. (Cahiers, 1926, XI, 410)

Perhaps not. Yet while he cuts all links between metrical verse and external guarantees, Valéry maintains there is a rhythmic instinct in man; a source of unanswerable questions it may be, but the organism responds to rhythms which correspond to certain vague structures within itself: 'A succession of noises is often taken for a rhythm but it is not quite a rhythm all on its own. It illuminates a rhythm in me' (Cahiers, 1914, V, 476). Explaining his return to poetry after twenty years (1892-1912), Valéry offers a newly heightened responsiveness to 
the sounds of language:

I found myself becoming sensitive once more to what sounds in utterances. I lingered over perceiving the music of language. The words I heard set off in me I know not what harmonic dependences and implicit presence of imminent rhythms. (E, I, 1492)

Valéry is careful not to reduce linguistic music to the mere sounds of words, but rather, to 'what sounds in utterances' (ce qui sonne dans les propos). His renewed sensitivity is not simply to the form of language, but rather, to the question of what it is, precisely, that we hear in language beyond the semantic content, and how that corresponds to the harmonic and rhythmic needs of the organism. Yet what, exactly, are these harmonic dependences and imminent rhythms? And what, precisely, is the nature of the 'utterances' which trigger his response? Does he mean all examples of language, from conversation to journalism, science, and literature, prose, and verse, or poetry read aloud? Valéry writes expansively on the differences between prose and poetry, and yet here, with uncharacteristic vagueness, it is the sounds of indeterminate 'propos' which offer music to his ear. This is a crucial question, since if language in its least literary incarnations is already musical, rhythmic, harmonious, then there is no need for poetry, indeed, poetry as a recognisable discourse disappears, since all language is already poetry. There must be something, therefore, which characterises poetic discourse as distinct from other utterances, and while Valéry omits to state with any certainty what this mysterious poetic quality is, it clearly has something to do with rhythm.

It is this sort of rhythmic instinct, Valéry suggests, that motivates free verse poets: 'They deliberately break with conventions, and for the cadences and musical substance of their verse, they rely on their rhythmic instinct and their delicate ear alone' (CE, I, 703). Similarly, a poet's first draft represents 'the immediate record of his personal rhythms, which are the form of his living energy system'. ${ }^{11}$ Yet the experience of these rhythms is always somehow problematic, and in 'La Création artistique' ('Artistic Creation'), Valéry gives a striking example of a rhythm:

which suddenly made itself very present in my mind, after a time during which I was only half-aware of this lateral activity. This rhythm imposed itself upon me, with a sort of insistence. (...) It seemed to me to want to take on a body, arrive at the perfection of being. But it could not become clearer to my consciousness without taking on some kind of sayable elements, syllables, words, and these 
syllables and words were probably, at this point in the process, determined by their musical value and attractions. It was a draft stage, childish, where the form and the material can hardly be distinguished from each other, the rhythmic form providing at that point the only condition of admission, or emission. (Vues, 300)

Rhythm here appears as pure, pre-linguistic, unsayable (indicible); it requires formulating in words, in order to exist, in order for us to apprehend it, and yet that expression in words also veils it sufficiently to protect its absolute quality. The nature of poetic rhythm, therefore, lies in a kind of oscillation between an undefinable pre-textual absolute and textual forms which point to its existence beyond them; and since none of those textual forms can ever be an exact representation of the absolute literary rhythm, genuine poetic rhythm, in opposition to the mechanical, metrical and predictable, must be complex, shifting, elusive.

\section{Rhythmic complexity}

Valéry expresses this complex rhythmical model through the rhythms produced by footsteps, either in walking or dancing. Although the correspondence between verse and a fundamental rhythmic regularity in man is tempting - Crow, for example, claims that 'the voice of poetry, too, is made of measured treads, of heartbeats" 12 - Valéry carefully avoids this notion of 'measured treads', or simple ambulatory regularity. The only footsteps in his verse, as in these examples from Charmes, are complex, irregular, inexpressible, or forever held back on the cusp of a virtual movement:

Les pas sidéraux ('Ode secrète', 1.13)

(The starry footsteps)

(...) des pas ineffables

Qui marquent dans les fables ('Cantique des colonnes', 11.71-72)

(unsayable footsteps

Which leave their mark in fables.)

Personne pure, ombre divine,

Qu'ils sont doux, tes pas retenus! ('Les Pas', 11.5-6)

(Pure person, divine shadow,

How sweet are your footsteps, held back!)

In the last example, the divine shadow of pure being does not walk, the poet preferring its footsteps when they remain pure potential, just as the homonym 'pas', the negator in French, cancels the verb which 
precedes it, and just as pure rhythm, which requires the impurity of words to embody it, can only remain pure on the brink of its expression in language.

References to footsteps in Valéry's cahiers develop this model of rhythmic complexity, such as this description of clambering down uneven rocks by the sea:

It is a dance, strange, because all the steps are different and none has the same amplitude or form as another; up, down, jumps, climbs, but a sort of rhythm remains (...) a dance whose steps' irregularity is the paradoxical law. (Cahiers, 1921, VIII, 224)

Eighteen years later, Valéry describes in detail a strange experience where the act of walking down a familiar street sets off a series of uncontrollable rhythmic connections of dizzying complexity:

As I walked along the street where I live, I was suddenly seized by a rhythm which imposed itself upon me, and which soon gave me the impression of working on me from outside. As if someone was using my life machine. Then another rhythm came to double the first and combine with it; and there established themselves I don't know what kind of transversal relationships between these two laws (I'm explaining it as best I can). This combined the walking movement of my legs with I know not what kind of song I was murmuring, or rather which murmured through me. This composition became more and more complicated, and soon became more complex than anything I could reasonably produce according to my ordinary, useable rhythmic faculties. Then the feeling of strangeness (...) became almost painful, almost worrying. I am not a musician; I am completely ignorant of musical technique; and here I was, prey to a development in several parts, more complicated than any poet could ever dream of. (CE, I, 1322)

This rhythmical illumination then disappears as suddenly as it had arrived. In contrast to previous descriptions of metrical inspiration, which arise from the poet's own mind, here the rhythms seem to possess him from outside. What is most striking is Valéry's insistence on a complexity which surpasses his understanding, which can only be experienced bodily rather than with the analytical mind. This, rather than simple regular footsteps, appears to be the real human experience of rhythms for Valéry. Poetic rhythm may well respond to, or provoke, a fundamentally human experience - 'poetry must extend to the whole being; it arouses our muscular organisation through its rhythms' (CE, I, 1394) - but nowhere does Valéry suggest that the experience of rhythm should be straightforward, regular, understandable. Rather, he tells us, 'there is a kind of pleasure which can be neither explained nor 
circumscribed' (CE, I, 1311). It is on this undefinable, inexpressible, multiple rhythmic experience that poetry relies: 'it is almost only via rhythm and the sensory properties of language that literature can reach the organic being of a reader with any confidence in the conformity between the intention and the results' (Vues, 291).

The implications for verse analysis of this conception of poetic rhythm are far-reaching, especially in light of Valéry's professed aversion to formal analysis itself: 'I do not believe in analyses of French poetry based on rhythmics, etc' (Cahiers, 1929-30, XIV, 274); ten years later, he repeats his conviction that 'analyses of poetry through metrics, prosody, phonetics are quite insufficient' (Cahiers, 1940, XXIII, 197). Valéry thus strongly counters the Parnassian belief that poeticity may be quantified formally: 'Try as we might to count the steps of the goddess, to note their frequency and average length, it will not teach us the secret of her instantaneous grace' (CE, I, 1285). Beauty may only now be defined as 'this uncertainty which confounds all calculations' (CE, I, 1287); indeed, 'to say that an object is beautiful is to give it the value of an enigma' (CE, I, 1301). It is the role of poetic rhythm, therefore, to preserve that mystery by simultaneously pointing towards, and holding back from, its imminent revelation, since 'Legs are not only for getting across and arriving - and words are not only for learning or teaching' (Cahiers, 1916, VI, 182).

While rhythm, then, survives the crise de vers as a vehicle for both experiencing and thinking poeticity, it acquires a new complexity and becomes so central to poetic discourse that, even in the absence of an external mimetic model, we are invited to imagine that it somehow exists beyond the text. Valéry argues that rhythmically and structurally complex verse actually creates the illusion of having sprung from real life, not unlike his strange experience of walking previously quoted:

Verse is that language in which the sonority and the linking of words, their signifying effect and their psychological resonances, the rhythms, the syntactic arrangements are so tightly bound that our memory is necessarily cleansed of them, and the words form an object which appears as if it were natural, as if it were born out of real life. (Cahiers, 1922, VIII, 586)

The important words here are 'as if' (comme). The complex, multiple and artificial structures of verse may at certain privileged moments appear to correspond to external rhythmical truths, indeed, it is the peculiar power of poetry to provoke precisely that illusion, but it 


\section{Paragraph}

remains an illusion nonetheless. Valéry describes himself succumbing to the same illusion in music: 'Beautiful music, you inspire my hatred and my desire. I know that you lie, and yet I follow you. You pretend to know, to hold - you recreate, you form and reform - and I know that you do not know and that you move us as if you led to the secret' (Cahiers, 1907-08, IV, 354). In an article which asks 'how to put prosody back at the centre of the way in which we think about poems and poetry $(. .$.$) how to understand prosody's elusive yet undeniable$ cognitive character', Simon Jarvis draws a similar conclusion: 'it is hard to escape the implication that there is something constitutively illusory about what it is that music attempts to express'. ${ }^{13}$ In an early letter to Gide, Valéry observes the same process in poetry: 'I have read the most marvellous Poe, Rimbaud, Mallarmé, analysed, alas, their methods, and each time I have come across the most beautiful illusions' (11891). ${ }^{14}$ It is this illusion, nurtured by poetry itself - that rhythm does exist out there - that we, as readers of poetry, are conditioned into accepting; Valéry is clearer than anyone on how this rhythmic illusion functions, and by placing a post-illusory formalism at the heart of his poetics, provides something like the 'kind of idealism - a sober, non-metaphysical, indeed an anti-metaphysical, almost, it may be thought, a materialist kind of idealism' upon which Jarvis's study concludes. ${ }^{15}$

\section{Rhythm as deferral}

Thanks to its rhythmic complexity and structural multiplicity, verse, for Valéry, can never be exhausted in the reading: 'A beautiful line of verse is reborn indefinitely from its ashes' (E, I, 1510), a 1929 formula which he takes up ten years later: 'the poem does not die for having lived: it is made expressly to be reborn from its ashes' (CE, I, 1331). This recalls Derrida's understanding of writing, as Peter Dayan puts it: 'Like music, writing cannot be said to arrive, it cannot reach us, cannot happen (...) but unlike music, as a thing, as a form, its duty is to be consumed, to vanish, to leave behind it only ashes'. ${ }^{16}$ Only unanalysable form, the kind to which Valéry's intricate verse structures aspire, can allow the text to be reborn from the ashes of the reading, and crucially, for Derrida, that capacity to escape fixity constantly is expressed as rhythm: 'As it escapes from all forms that writing can determine, it acquires the force of rhythm (...) not analysable rhythm, not representable form, but a kind of rhythm which always 
escapes, and must always be re-thought, re-invented, re-imagined'. ${ }^{17}$ Unlike prose which, Valéry often argues, exists to take the reader from $A$ to $B$, with $B$ representing the final term to be understood, the rhythmic fabric of verse enacts formally the fundamental impossibility of concluding, since 'if everything were deciphered, everything would disappear instantaneously' (CE, II, 506). Indeed, for Valéry, the essence of poetry is a resistance to closure, a constant hesitation:

The poetic idea (...) a clear ambiguity, presenting in a fragment, on a given point, the resonance of the whole being. (Cahiers, 1915, V, 637)

The poet's business is to construct a sort of verbal body which might have the solidity, but the ambiguity, of an object. (Cahiers, 1916, VI, 118)

Ambiguity is the rightful domain of poetry. (Cahiers, 1916, VI, 343)

This state of poetry is perfectly irregular, inconstant, involuntary, fragile. (CE, I, 1321)

Whoever looks for one single, fixed truth in 'la forêt enchantée du Langage' (the enchanted forest of Language), Valéry explains, is doomed to disappointment:

The huntsman who gets worked up chasing the 'truth', following a single, continuous path, of which each element is the only one he must take, for fear of losing the path or the gains of the road hitherto travelled, risks capturing only his/its shadow. Gigantic, sometimes; but a shadow nonetheless. (E, I, 1300-01)

In a typically Mallarmean piece of sleight of hand, it is unclear from the French what the possessive in 'ne capturer enfin que son ombre' refers to; does the truth-seeker find a shadow of the truth he was searching for, or a shadow of himself? Is the truth in art an internal, human truth, or does it exist out there, in language, in the universe? Surely, as we have seen, that ambiguity is central to poetry, and it is rhythm which helps the poet maintain this quintessentially poetic hesitation, fuelling but never satisfying our 'need to find a suitable definition of poetry, at the very least a decisive characteristic - and this need itself is born of our inability to discover the real poetic principle' (Cahiers, 1918, VII, 71).

It is in rhythm that Valéry locates the universally human response to poetry, a rhythm which provides no answers, which resists definition, and yet which, in its mystery and complexity, represents the truth of 


\section{Paragraph}

both the human condition and the poetic enterprise: 'Why not admit that man is the source, the origin of enigmas, since there is no object, no being, no instant which is not impenetrable' ( $E$, I, 650). Just as Mallarmé's famously mysterious 'obscure' poems work by 'making you expect and desire some resolution' (Cahiers, 1940-41, XXIV, 150) and yet by constantly deferring it, Valéry's theory of rhythm establishes a sense of familiarity, or recognition, a desire for resolution, and yet its complexity resists our understanding, allowing verse to be born again with every reading. As Robert Pickering observes, 'rhythm, for Valéry, is a concept in a state of perpetual becoming'. ${ }^{18}$ Moreover, it is a state which both needs language in which to manifest itself, and yet rejects it, providing its own sort of truth, a state which approaches that imagined by Simon Jarvis: 'If we can imagine forms of thinking and knowing which are not linguistic, and which do not rest upon linguistic modes of making-explicit, then we are also in that act imagining meanings and ways of meaning which are not like the relation of a signifier to a signified'. ${ }^{19}$ Rhythm, then, is always in process, never fixed; always mobile, unstable; it provides no clear answers, but rather, provokes unanswerable questions, and it is this elusive, challenging, unsettling characteristic which ensures rhythm remains central to twentieth-century poetry and its exploration of what it means to be human and in the world, teasing us with the promise of answers which it perpetually defers.

\section{NOTES}

1 Valéry's italics. The italics in all quotations are Valéry's own. References to Valéry's prose are from CEuvres, edited by Jean Hytier (Paris: Gallimard, coll. 'Bibliothèque de la Pléiade', 1957) and Ego scriptor, edited by Judith Robinson-Valéry (Paris: Gallimard, coll. 'Poésie', 1992), which contains selections from his Cahiers in chronological order. French verse will be given in the original with accompanying translation, while prose will be given in English only, unless commented on at the level of the signifier. All translations are my own.

2 See Benoit de Cornulier, Théorie du vers (Paris: Seuil, 1982), 133-44 for an explanation of the various types of caesural infringement.

3 Letter to Jacques Doucet, 1922, quoted in Brian Stimpson, Paul Valéry and Music (Cambridge: Cambridge University Press, 1984), 175.

4 In another striking parallel with Emma Sutton's opening quotation, this echoes Woolf's suggestion that the writer has not to fix rhythm in the text, but rather to set it working. 
5 One of the strengths of Henri Meschonnic's Critique du Rythme (Lagrasse: Verdier, 1982) is its similarly staunch refusal to see poetic rhythm as a mimesis of cosmic or bodily rhythms; see the sections entitled 'L'imitation cosmique' (617-42) and 'Critique de l'anthropologie du rythme' (643-702).

6 Victor Hugo, Les Contemplations (Paris: Gallimard, 1973), 376.

7 Walter Ince, 'Some of Valéry's reflections on rhythm', in Baudelaire, Mallarmé, Valéry: New Essays in Honour of Lloyd James Austin, edited by Malcolm Bowie, Alison Fairlie and Alison Finch (Cambridge: Cambridge University Press, 1982), 384-97 (395) and Christine Crow, Paul Valéry and the Poetry of Voice (Cambridge: Cambridge University Press, 1982), 83.

8 Hugo, Océan. Faits et croyances, in Euvres complètes, 18 vols, edited by Jean Massin (Paris: Le Club Français du Livre, 1967-70), VII, 700.

9 La Jeune Parque (Paris, Gallimard, 1974), 17.

10 Frédéric Lefevre, Entretiens avec Paul Valéry (Paris: Le Livre, 1926), 62.

11 'Comment travaillent les écrivains', Vues (Paris, La Tables Ronde, 1948), 317.

12 Paul Valéry and the Poetry of Voice, 149.

13 'Musical Thinking: Hegel and the Phenomenology of Prosody', Paragraph $28: 2$ (July 2005), 57-71 (57 and 65).

14 1891, Gide-Valéry Correspondance (Paris, 1955), 126.

15 'Musical Thinking', 69; Jarvis's italics.

16 'Derrida Writing Architectural or Musical Form', Paragraph 26:3 (November 2003), 70-85 (83).

17 'Derrida Writing Architectural or Musical Form', 82.

18 “"Tes pas... procèdent”: melos, marche, méditation dans les promenades de Rousseau et de Valéry', in Paul Valéry: Musique, mystique, mathématique, edited by Paul Gifford and Brian Stimpson (Lille: Presses Universitaires de Lille, 1993), 95-112.

19 'Musical Thinking', 69. 